(C) С.Д. Хіміч, О.М. Чемерис, Є.С Варивода, 2018

УДК 616-001-031.82-056.52-089

\title{
Деякі аспекти хірургічної курації політравмованих пацієнтів із ожирінням
}

\author{
С.Д. Хіміч, ${ }^{1}$ О.М. Чемерис, ${ }^{2}$ С.С Варивода ${ }^{2}$ \\ s-khimich@ukr.net \\ ${ }^{1}$ Вінницький національний медичний університет імені М.І. Пирогова, Вінниия; \\ ${ }^{2}$ Львівський національний медичний університет імені Данила Галицького, Львів
}

\section{Реферат}

Вступ. Ожиріння є одним із чинників, який підвищує ризик травматизму як у побутовому житті, так і на робочому місці.

Мета дослідження. Визначити особливості та основні аспекти хірургічної курації за потерпілими 3 поєднаною травмою тіла, які страждають на ожиріння.

Матеріали та методи. Клінічний матеріал склали 103 пацієнти з поєднаною травмою тіла, які знаходилися на стаціонарному лікуванні у клініці хірургії протягом 2003-2018 років.

Результати досліджень та їх обговорення. У пацієнтів з нормальною масою тіла у процесі діагностики і лікування не спостерігали жодних особливостей, які б не відповідали загальноприйнятим стандартам плану хірургічної курації хворих.

У потерпілих з ожирінням визначали певні особливості, з якими зіткнулися «команда лікарів політравми». За відсутності катетеризованої периферійної чи центральної вени, що призводило до проблеми адекватного знеболення, дозування і введення лікарських препаратів, труднощів при інтубації та виборі параметрів штучної вентиляції легень, санацію бронхіального дерева здійснювали через трахеостомічну трубку. При ожирінні надавали перевагу збалансованим сумішам для ентерального харчування, що пов'язано із необхідністю ранньої стимуляції моторики шлунка та кишківника. Тромбоемболію дрібних гілок легеневої артерії пов'язували 3 наявністю як травми, так $\mathrm{i}$ ожиріння, що могло бути зумовлено утворенням специфічних протромботичних факторів з боку жирової тканини, а також дисфункціями тромбоцитів.

Висновки. Курація політравмованих хворих із ожирінням має цілий ряд особливостей, пов'язаних із анатомічними особливостями будови і впливу надлишкового жиру на перебіг фізіологічних процесів в організмі при травмі.

Ключові слова: ожиріння, політравма, хірургічна курація

Some aspects of surgical curation of obese patiets suffer polytrauma

Khimich S.D., ${ }^{1}$ Chemerys O.M., ${ }^{2}$ Varyvoda E.S. ${ }^{2}$

National Pirogov Memorial Medical University, Vinnytsya ${ }^{1}$

Danylo Halytsky Lviv National Medical University, Lviv ${ }^{2}$

Introduction. Obesity is one of the factors that increases the risk of injury, both in everyday life and in the workplace.

The aim of the study. Identify the main aspects of surgical curatorship of obese patients suffer combined body injury.

Materials and methods. Clinical material was 103 patients with combined body trauma, who were treated at the surgery clinic during 2003-2018.

Results. Patients with normal body weight didn't have any peculiarities in diagnosis and treatment differ from accepted standards of the surgical management.

A polytrauma «doctor team» identified some feature in obese patients. It includedan adequateanesthesia in case of absence catheterized peripheral or central vein, dosage and administration of drugs, difficult intubation andparameter's correction ofmechanical lungs ventilation. Bronchial sanation was performed through the tracheostomy tube.

We prefer enteral nutrition for better early stimulation of the stomach and intestine motility for obese patients. The pulmonary thromboembolism of the small arteries was associated with the presence of both trauma and obesity. It caused by formation of specific prothrombotic factors on the part of adipose tissue, as well as thrombocyte dysfunctions.

Conclusion. The curatorship of obese patients sufferpolytrauma with has some peculiarities associated with the anatomical features of the body structure and the effect of excess fat on the course of physiological processes as a trauma complications.

Key words: obesity, polytrauma, surgical curatorship

Вступ. За даними Buchwald (США, 2007 р.), сьогодні у світі майже два мільярди людей мають надмірну вагу, що дорівнює кількості тих, хто страждає від голоду. Всесвітня організація охорони здоров'я (ВОО3) спрогнозувала, що до 2020 року приблизно 2,3 мільярда дорослих матимуть надвагу, а більше 700 мільйонів - ожиріння $[1,2]$. Незважаючи на те, що США вважа- ють світовим лідерому чисельності людей 3 ожирінням, частка таких осіб у країнах Європи невпинно зростає [3]. Підраховано, що хронічні захворювання на тлі ожиріння спричиняють близько $43 \%$ смертей на грунті серцевосудинних захворювань, цукрового діабету, гіпертонії та дисліпідемії, які не достатньо діагностуються і відповідно лікуються [4,5]. 
Ожиріння створює додатковий фінансовий тягар для системи охорони здоров'я. У США річні витрати на здоров'я, пов'язані з захворюваннями, спричиненими ожирінням, приблизно на 1500 доларів більше, ніж у пацієнтів 3 нормальною масою тіла [6]. Ожиріння є одним із чинників, який підвищує ризик травматизму як у побутовому житті, так і на робочому місці, а поєднані пошкодження тіла спричинені дорожньо-транспортними пригодами посідають одне із домінуючих позицій у загальній структурі сучасної політравми даної категорії потерпілих, що в сукупності зумовлює неабиякі виклики у медичній галузі $[7,8]$.

Ще одним iз не менш важливих аспектів окресленої проблеми є догляд за такими потерпілими, адже 3 моменту отримання травми медичний персонал стикається з великою кількістю ситуацій, не пов'язаних із безпосереднім наданням медичної допомоги. Питання дорожньої іммобілізації, шинування, евакуації з осередку катастрофи у машину екстреної допомоги, транспортування до стаціонару i безпосередньо курація пацієнтів під час госпітального етапу породжують численні особливості діагностики, лікування, медичного догляду, як наслідок, нестандартних рішень [9].

Мета дослідження. Визначити особливості та основні аспекти хірургічної курації за потерпілими 3 поєднаною травмою тіла, які страждають на ожиріння.

Матеріали та методи. Клінічний матеріал склали 103 пацієнти з поєднаною травмою тіла, які знаходилися на стаціонарному лікуванні у клініці хірургії протягом 2003-2018 років. Вік потерпілих коливався в межах від 18 до 76 років (середній вік $41,3 \pm 1,7$ р.). Жінок було 49 (47,6 \%), чоловіків - 54 (52,4\%), осіб працездатного віку - 64 (62,1\%). У хворих були травми різної локалізації і тяжкості пошкодження.

Усі пацієнти були госпіталізовані у проміжку від 20 хвилин до 1,5 год. від моменту отримання травми, що склало в середньому 41,7 $\pm 1,3$ хв. За обста- винами отримання травми переважали дорожньотранспортні пригоди (водій, пасажир або пішохід) 61 особа (59,2 \%), у 29 (28,2 \%) випадків - падіння 3 висоти 3-6 метрів, у 13 (12,6 \%) - побиття іншими особами.

Дослідження проводили у два етапи. На I етапі обчисляли індекс маси тіла (IMT) потерпілих як найбільш широко визнаного інструменту для визначення ожиріння. Його розрахунок відносно простий та недорогий, оскільки це математична формула, яка базується на відношенні маси тіла (кг) до зросту $\left(\mathrm{M}^{2}\right)$, а також визначає відносний ризик при різних захворюваннях і смертності. Однією 3 проблем використання IMT як інструменту вимірювання було те, що дуже м'язисті люди могли потрапляти у категорію зайвої ваги, де насправді іiі немає. Залежно від значення IMT здійснювали розподіл на клінічні групи і визначали тяжкість пошкоджень за шкалою PTS [10].

На II етапі визначали особливості хірургічної курації пацієнтів на різних етапах госпітального лікування з урахуванням IMT.

Діагностику і лікування пацієнтів з політравмою проводили згідно з загальноприйнятими та локальними протоколами, які включали збір та аналіз скарг, анамнезу захворювання та життя, клінічної картини на різних етапах перебування пацієнта (догоспітальному етапі та стаціонарі), особливостей травмуючого чинника.

Результати досліджень та їх обговорення. Залежно від значення IMT усіх потерпілих було розподілено на три клінічні групи. До першої групи увійшло 29 (28,2 \%) хворих із нормальною масою

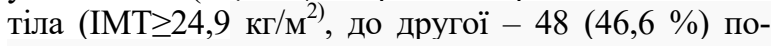
терпілих із надвагою тіла та ожирінням I ст. $\left(\mathrm{IMT}=26,2-34,2 \mathrm{\kappa г} / \mathrm{M}^{2)}\right.$ та до третьої - 26 (25,2\%) травмованих із ожирінням II- III ст. (IMT=35,3$41,9 \kappa \Gamma / \mathrm{M}^{2)}$.

Локалізація і варіанти закритих ушкоджень анатомічних ділянок тіла при політравмі представлено у таблиці 1.

Таблиця 1

Поєднані пошкодження тіла

\begin{tabular}{|l|c|}
\hline \multicolumn{1}{|c|}{ Варіант поєднаних ушкоджень } & Кількість осіб, (\%) \\
\hline $\begin{array}{l}\text { Травма голови }+ \text { травма грудної клітки }+ \text { травма живота }+ \\
\text { травма тазу + скелетна травма }\end{array}$ & $67(65,0 \%)$ \\
\hline Травма грудної клітки + травма живота & $24(23,3 \%)$ \\
\hline Травма живота + скелетна травма & $12(11,7 \%)$ \\
\hline
\end{tabular}

Тяжкість отриманих пошкоджень за шкалою PTS на момент поступлення до стаціонару представлено у таблиці 2 .

Таблиця 2

Тяжкість отриманих пошкоджень за шкалою PTS

\begin{tabular}{|l|c|c|c|}
\hline & Стан середньої тяжкості & Тяжкий стан & Вкрай тяжкий стан \\
\hline І клінічна група & $27(26,2 \%)$ & $2(1,9 \%)$ & - \\
\hline II клінічна група & $7(6,8 \%)$ & $34(33,1 \%)^{*}$ & $7(6,8 \%)$ \\
\hline III клінічна група & - & $9(8,7 \%)$ & $17(16,5 \%)^{*} *$ \\
\hline Загалом & $34(33,0 \%)$ & $45(43,7 \%)$ & $24(23,3 \%)$ \\
\hline
\end{tabular}
* статистично дотовірні зміни $(\mathrm{p}>0,02)$
* статистично дотовірні зміни (p >0,04)

78 Науковий вісник Ужгородського університету, серія «Медииина», випуск 2 (58), 2018 р. 
Наступний етап дослідження полягав у 3'ясуванні особливостей надання допомоги політравмованим пацієнтам залежно від IMT. У пацієнтів I клінічної групи у процесі діагностики i лікування не спостерігали жодних особливостей, які б не відповідали загальноприйнятим стандартам плану хірургічної курації хворих.

У потерпілих II та III клінічних груп визначали певні особливості, 3 якими стикалася команда лікарів, особливо у випадках II-III ст. ожиріння. Найпершими із труднощами стикалися лікарі анестезіологи у критичні моменти надання невідкладної медичної допомоги, що було зумовлено вибором методу введення та адекватного дозуванням лікарських препаратів. Слід відзначити, що внутрішньом'язові ін'єкції у хворих 3 ожирінням взагалі недоречно застосовувати, адже у них підшкірна клітковина настільки виражена, що досягнути голкою м'язу практично у 100 \% випадків неможливо [1]. Саме 3 тієї причини людей 3 ожирінням тяжче було адекватно знеболити, включаючи на догоспітальному етапі, і в умовах приймального відділення за відсутньої катетеризованої периферійної чи центральної вени, що було одним із додаткових шокогенних факторів, який на відміну від потерпілих 3 ожирінням швидко вдавалося купувати у пацієнтів I клінічної групи.

Тимчасове використання кількох периферійних вен для інфузій було допустимим у політравмованих з нормальної масою тіла, проте це категорично виявилось протипоказами при ожирінні, оскільки таким способом не вдавалося компенсувати об'єми циркулюючих рідин. Враховуючи це, усім 48 хворим II (46,6 \%) та 26 потерпілим III (25,2 \%) клінічних груп відразу катетеризували підключичні вени з обох боків. Слід відзначити, що час виконання маніпуляції з одного боку у потерпілих 3 ожирінням був більшим у порівнянні з хворими I клінічної групи $(2,1 \pm 1,3$ хв. vs $5,3 \pm 1,2$ хв.; $>>0,05)$. При дозуванні і уведенні лікарських препаратів враховували наявність великої маси жирових відкладень, які мали значний вплив на метаболізм і розподіл лікарських засобів.

Ще $з$ одними труднощами лікарі анестезіологи зіткнулися при інтубації трахеї, оскільки сам процес додатково ускладнювався внаслідок зниженої рухливості шиї та обмеженої візуалізації через товщину м'яких тканин у пацієнтів 3 ожирінням, адже у них, як правило, «коротка товста» шия, яка породжувала тяжкий ендотрахальний шлях. Тривалість інтубації значно подовжувалася і складала $(4,3 \pm 1,5$ хв. $v s 13,1 \pm 1,7$ хв.; $\mathrm{p}>0,03)$.

Нами відзначено, що початкові параметри апарату штучної вентиляції легень (ШВЛ) повинні відповідали показникам для нормальної маси тіла, а не фактичній масі тіла, що дозволяло уникнути додаткової баротравми. Появу ранніх респіраторних ускладнень при ожирінні пов'язували 3 явищами аспірації (25,2%; III клінічна група) та обмеженою рухливістю стінок грудної клітини і як наслідок, зміненої легеневої механіки. Наведені чинники подовжували тривалість ШВЛ у II та III клінічних групах, що відповідало $(3,9 \pm 1,5$ доби $v s 9,2 \pm 1,4$ доби; $\mathrm{p}>0,02)$.

3 метою ендоскопічної санації трахеобронхіального дерева на 3-4 добу хворим виконували трахеостомію. У пацієнтів 3 ожирінням технічне виконання було складнішим, у зв'язку із анатомічними особливостями - «короткою шиєю» у поєднанні із різко вираженою підшкірножировою клітковиною. Також звертали увагу на розмір і форму трахеостомічних трубок, для хворих $з$ ожирінням вони мають бути довшими і вигнуті під гострим кутом.

У $12(11,7 \%)$ хворих III клінічної групи було діагностовано тромбоемболію дрібних гілок легеневої артерії. Дане ускладнення ми пов'язували 3 наявністю як травми, так і ожиріння, що могло бути зумовлено утворенням специфічних протромботичних факторів 3 боку жирової тканини, а також дисфункціями тромбоцитів. Це сприяло розвитку посттравматичного тромбозу глибоких вен та ризику інсульту чи гострого інфаркту міокарда. Тому профілактику тромбоемболічних ускладнень необхідно здійснювати усім потерпілим з поєднаною травмою тіла, особливо які страждають на ожиріння.

Після виведення потерпілого із травматичного шоку, поставало питання нутриційної підтримки хворого. Харчування пацієнтів I клінічної групи здійснювали відповідно до загальноприйнятих стандартів шляхом комбінації парантеральних та ентеральних сумішей, які вводили через назогастральний зонд.

Потерпілим із ожирінням надавали перевагу збалансованим сумішам для ентерального харчування, що пов'язано із необхідністю ранньої стимуляції моторики шлунка та кишківника. Ранні парези травного тракту ми спостерігали у 34 (33,0 \%) потерпілих (II-III клінічні групи) і трактували, як результат інтраабдомінальної гіпертензії за рахунок наявного в даної групи хворих внутрішньочеревного жиру.

Підсумовуючи вищенаведене, ще раз хочемо привернути більшу увагу лікарської спільноти до «ожиріння», як не лише до соціальної, а безпосердньо медичної проблеми, оскільки частка людей, які на нього страждають протягом останніх років, зростає [3,9]. Такі хворі потребують особливого диференційованого підходу, адже надлишкова маса тіла створює додаткові труднощі не тільки у діагностично-лікувальному процесі, а і у хірургічному догляді. Врахування виникнення наведених «труднощів» лікування таких постраждалих на тлі ожиріння, удосконалення навичок ведення адекватної інфузійної підтримки, наркотичного знеболення, респіраторної підтримки і харчування дозволило нам сформували підгрунття для побудови кращої діагностично-лікувальної стратегіï, a, отже, покращити результати та відда- 
лені наслідки при наданні допомоги політравмованим пацієнтам.

Висновки. Курація політравмованих хворих із ожирінням має низку особливостей, пов'язаних із анатомічними особливостями будови тіла і впливу надлишкового жиру на перебіг фізіологічних про- цесів в організмі при травмі. Надання медичної допомоги даній групі потерпілих на різних етапах необхідно здійснювати з урахуванням усіх відмінностей оцінки тяжкості загального стану, догоспітальної стабілізації та медичного супроводу впродовж стаціонарного лікування.

Інформація про конфлікт інтересів. Автори заявляють про відсутність конфлікту інтересів при виконанні наукового дослідження та підготовці даної статті.

Інформація про фінансування. Автори гарантують, що вони не отримували жодних винагород в будь-якій формі, здатних вплинути на результати роботи.

Особистий внесок кожного автора у виконання роботи:

Хіміч С.Д. - загальна ідея дослідження;

Чемерис О.М. - набір клінічного матеріалу;

Варивода С.С. - аналіз результатів.

\section{Список використаної літератури}

1. Khimich SD. Dotsilnist vykonannia vnutrishnom'iazovykh in'iektsii tradytsiinymy holkamy patsiientam z ozhyrinniam. Visnyk Vinnytskoho natsionalnoho medychnoho universytetu. 2010;14(2: 256-259. [in Ukrainian]. 2. Christmas AB, Reynolds J, Wilson AK, et al. Morbid obesity impacts mortality in blunt trauma. Am Surg. 2007;73(11):1122-5

3. Kouvonen A, Kivimäki M, Oksanen T, et al. Obesity and occupational injury: A prospective cohort study of 69,515 public sector employees. PLoS One. 2013;8(10):e77178.

4. Liu T, Chen J, Bai X, et al. The effect of obesity on outcomes in trauma patients: A metaanalysis. Injury. 2013;44(9):1145-1152.

5. Evans DC, Stawicki SPA, Davido HT, et al. Obesity in trauma patients: Correlations of body mass index with outcomes, injury patterns, and complications. Am Surg. 2011;77(8):1003-1008.

6. Domi R, Laho H. Anesthetic challenges in the obese patient. J Anesth. 2012;26:758-765.

7. Mica L, Keller C, Vomela J, et al. Proper catheter selection for needle thoracostomy: A height and weightbased criteria. J Trauma Acute Care Surg. 2013;75(4):693-698.

8. Glance LG, Li Yue, Osler TM, et al. Impact of obesity on mortality and complications in trauma patients. Ann Surg. 2013;00:1-6.

9. Mica L, Keller C, Vomela J, et al. Obesity and overweight as a risk factor for pneumonia in polytrauma patients: A retrospective cohort study. J Trauma Acute Care Surg. 2013;75(4):693-8.

10. Winfield RD, Bochicchio GV. The critically injured obese patient: A review and a look ahead. J Am Coll Surg. 2013;216(6):1193-1206.

Стаття надійшла до редакції: 31.01.2018 р. 